Creative Commons User License: CC BY-NC-ND

Abstracted by: EBSCOhost, Electronic Journals Service (EJS),

Google Scholar, Journal Seek, Scientific Commons,

Food and Agricultural Organization (FAO), CABI and Scopus

http://eoi.citefactor.org/10.11226/v25i4
Journal of Agricultural Extension

Vol. 25 (4) October, 2021

ISSN(e): 24086851; ISSN(Print); 1119944X

http://journal.aesonnigeria.org

http://www.ajol.info/index.php/jae

Email: editorinchief@aesonnigeria.org

\title{
Self-Esteem of Agriculture Students at the University of Ibadan and the Federal University of Agriculture Abeokuta, Nigeria \\ https://dx.doi.org/10.4314/jae.v25i4.1
}

\section{Badiru, Idris Olabode}

Department of Agricultural Extension and Rural Development, University of Ibadan, Ibadan.

Email: bodebadru@gmail.com; Phone number: 08034660732

\section{Oguntala, Funmilola Omolola}

Department of Agricultural Extension and Rural Development, University of Ibadan, Ibadan

Email: funmiwi@gmail.com; Phone number: 08168116974

\section{Sanusi, Mohammed Kabiru}

Nigerian Institute for Oil-Palm Research (NIFOR), Date palm Sub-station, Dutse, Jigawa

State

Email: sanusimk2004@gmail; Phone number: 08033638872

\section{Abstract}

The study investigated self-esteem of agriculture students of the University of Ibadan and the Federal University of Agriculture Abeokuta in Southwestern, Nigeria. Multi-stage sampling procedure was used to select 117 and 124 students from the conventional university and agriculture-based university respectively. A structured questionnaire was used in data collection and analysed with percentages, Chi-square, PPMC and independent t-test.

The students from the University of Ibadan (UI) preferred medicine $(\bar{x}=1.14)$, had unfavourable perception (87.2\%) about agriculture and low self-esteem (85.5\%) while students from the Federal University of Agriculture Abeokuta (FUNAAB) preferred agriculture ( $\bar{x}=1.48)$, had favourable perception (82.7\%) about agriculture and high self-esteem (89.5\%). Self-esteem was significantly related to family structure and preferred course of study in UI while sex and perception towards agriculture is significantly related to self-esteem of students in FUNAAB. There were significant differences in self-esteem of students in UI and FUNAAB and that of 100 level and 500 level students in UI. School counsellors should promote careers and opportunities in agriculture to make it popular and attractive to the students.

Keywords: Self-esteem and agriculture, preferred course, agricultural students and career in agriculture.

\section{Introduction}

Agriculture remains a major occupation all over the world. In Nigeria, Agriculture has been the backbone of the country's economy providing employment for about 36 percent of the labour force and contributing about 22 percent to the GDP in the first 
Creative Commons User License: CC BY-NC-ND

Abstracted by: EBSCOhost, Electronic Journals Service (EJS),

Google Scholar, Journal Seek, Scientific Commons,

Food and Agricultural Organization (FAO), CABI and Scopus

http://eoi.citefactor.org/10.11226/v25i4
Journal of Agricultural Extension

Vol. 25 (4) October, 2021

ISSN(e): 24086851; ISSN(Print); 1119944X

http://journal.aesonnigeria.org

http://www.ajol.info/index.php/jae

Email: editorinchief@aesonnigeria.org

quarter of 2020 (Oyaniran, 2020). Agriculture has broad scope with many career opportunities which can build one's self-esteem and self-worth. According to Environmental Science (2021) the list of career opportunities open for students of agriculture includes and not limited to: production of various crops, fishing, poultry, rabbit production, distribution of farm products, officials of agricultural agencies, research institutes and agro-allied industries.

With over 17 agricultural research and international agriculture research institutes, colleges of agriculture, faculties of agriculture and universities of agriculture across the country, the agricultural sector cannot be left in the hands of quacks, low esteemed individuals. In contrast, all-round, well trained, intelligent, well-motivated, high spirited personnel with vibrant minds and high self-esteem are required to occupy the vacancies in the industry, so that all the expected goals attached to agriculture can be achieved. The realisation of the importance of agriculture to the country made educationalists and the government to make provision in the National Policy on Education for practical agriculture in the curriculum of the Junior Secondary School and agricultural science in the Senior Secondary School curriculum as core subjects (Ojimba, Nwafor, Chigekwu and Onyekwere, 2018). This further led to the introduction of professional courses in the conventional universities and the establishment of agriculture-based universities to provide manpower for agriculture related enterprises.

Despite the contribution of agriculture to economic growth, there are skill and labour shortages in the sector due to lack of interest and low self-esteem of the youths in venturing into agriculture as a career path. This led to the problem of rural-urban drift; a situation where the youth who would have stayed in the rural areas to engage in one form of agriculture or the other move to the cities to constitute nuisance and mounting pressure on urban facilities (Delango, 2019). World Bank, (2020) reported that there has been a considerable decrease in rural population from $66.4 \%$ in 1960 to $43.9 \%$ in 2020 , while Basil and Omole (2017) concluded that rural-urban drift is detrimental to agricultural development.

According to Feed the Future, (2020) youths generally have poor perception of career in agriculture. This perception could affect the self-perception and by extension the self-esteem of a youth who finds him/herself in the field of agriculture. Ahmed (2016) defined self-esteem as individual's perception or subjective appraisal of one's own self-worth, one's feelings of self-respect and self-confidence and the extent to which the individual holds positive or negative views about self. Selfesteem affects people's trust in others, one's relationships, one's work; nearly every 
Creative Commons User License: CC BY-NC-ND

Abstracted by: EBSCOhost, Electronic Journals Service (EJS),

Google Scholar, Journal Seek, Scientific Commons,

Food and Agricultural Organization (FAO), CABI and Scopus
Journal of Agricultural Extension

Vol. 25 (4) October, 2021

ISSN(e): 24086851; ISSN(Print); 1119944X

http://journal.aesonnigeria.org

http://www.ajol.info/index.php/jae

Email: editorinchief@aesonnigeria.org

part of one's lives such as financial success, health status and personal fulfilment in life.

The influence of teachers and support for students have equally been recognised as an important factor affecting students' self-esteem (Wangia, Waswa and Waudo, 2019). Teachers can articulate interest in students' career goals, boost their selfesteem and serve as role models and have shown to be instrumental in influencing students' choices in agricultural science. Junyi, (2018) affirmed the roles of teachers in building self-esteem, career choice and planning of students. Stair, Danjean, Blackburn and Bunch, (2016), enumerated factors that limit students or individual choice to study agriculture or agricultural occupations to include personal characteristics, interpersonal factors, and environmental factors. Hence, understanding these factors limiting the choice of agriculture as a career is important to improve self-esteem of the students and promote stronger career opportunities for agriculture.

Gaining admission into university to study courses of interest is the joy of all students. However, some students have sufficient scores to pursue courses of interest, while others do not. They thereby have to abandon courses of interest for courses that are considered to best suit their scores at various entrance examinations. This could lead to low self-esteem for many students, including those studying agriculture. Agriculture students especially, could also be battling with low self-esteem as a result of negative misconceptions about agriculture as a career among other reasons. Therefore, many students of agriculture, especially first year students, often feel unhappy studying agriculture compared to other students studying engineering, medicine and pharmacy. This could be due to lack of incentives and political will to encourage agricultural education on the part of the government. However, many of these assertions and the effects of peer influence on the self-esteem of the students are not backed by empirical evidences. Therefore, the self-esteem of agriculture students in conventional and agriculture based universities in Southwestern, Nigeria was examined. The specific objectives were to determine the respondents' preferred courses of study, examine the respondents' perception of agriculture as a career choice and assess the self-esteem of the students.

The study hypothesised as follows:

1. There is no significant relationship between selected personal characteristics and self-esteem of the students. 
Creative Commons User License: CC BY-NC-ND

Abstracted by: EBSCOhost, Electronic Journals Service (EJS),

Google Scholar, Journal Seek, Scientific Commons,

Food and Agricultural Organization (FAO), CABI and Scopus

http://eoi.citefactor.org/10.11226/v25i4
Journal of Agricultural Extension

Vol. 25 (4) October, 2021

ISSN(e): 24086851; ISSN(Print); 1119944X

http://journal.aesonnigeria.org

http://www.ajol.info/index.php/jae

Email: editorinchief@aesonnigeria.org

2. There is no significant relationship between preferred course of study and self-esteem of the students.

3. There is no significant relationship between perception of agriculture as a course of study and self-esteem of the students

4. There is no significant difference in the self-esteem of students in agriculture based and conventional universities.

5. There is no significant difference in the self-esteem of students in 100 level and 500 level.

\section{Methodology}

The study was carried out in the Faculties of Agriculture, University of Ibadan and the Federal University of Agriculture, Abeokuta, Ogun State. The Faculty of Agriculture University of Ibadan has the following departments: Agricultural Economics, Agricultural Extension and Rural Development, Agronomy, Animal Science, Crop Protection and Environmental Biology. The Faculty of Agriculture, University of Ibadan was founded in 1949 as a centre for agricultural advancement by application of scientific research and training.

The Federal University of Agriculture, Abeokuta (FUNAAB) was established on first of January, 1988. FUNAAB has 8 colleges namely the College of Agriculture Management and Rural Development (COLAMRUD), College of Food Science and Human Ecology (COLFHEC), College of Animal Science and Livestock Production (COLANIM), College of Environmental Resources Management (COLERM), College of Physical Sciences (COLPHYS), College of Biological Sciences (COLBIOS), College of Plant Science Crop Protection (COLPLANT) and College of Management Sciences (COLMAS). The colleges comprise 13 departments, namely agricultural administration, agricultural extension and rural development, agricultural economics and farm management, animal production and health, animal nutrition, animal physiology, animal breeding and genetics, pasture and range management, crop protection, plant physiology and crop production, soil science and land management, plant breeding and seed technology and horticulture.

The population of the study consists of all 100 level and 500 level students (2018/2019 session) in the Faculties of Agriculture University of Ibadan, Oyo State and equivalent colleges at the Federal University of Agriculture, Abeokuta (FUNAAB), Ogun State. Multi-stage sampling procedure was adopted for the study that involves different stages for the two selected institutions based on the peculiarities of the structure of the school. In FUNAAB the first stage involved purposive selection of 100 level and 500 level students from the three colleges 
Creative Commons User License: CC BY-NC-ND

Abstracted by: EBSCOhost, Electronic Journals Service (EJS),

Google Scholar, Journal Seek, Scientific Commons,

Food and Agricultural Organization (FAO), CABI and Scopus
Journal of Agricultural Extension

Vol. 25 (4) October, 2021

ISSN(e): 24086851; ISSN(Print); 1119944X

http://journal.aesonnigeria.org

http://www.ajol.info/index.php/jae

Email: editorinchief@aesonnigeria.org

dealing directly with agriculture. The colleges were COLAMRUD which comprises of departments: agricultural extension and rural development, agricultural economics and farm management and agricultural administration; COLANIM which comprises of departments: animal breeding and genetics, animal nutrition, animal physiology, animal production and health and pasture and range management and COLPLANT which comprises of departments: crop protection, plant physiology and crop production, soil science and land management, plant breeding and seed technology and horticulture.

The second stage involved random selection of two departments each from the selected Colleges. In COLAMRUD, department of agricultural extension and rural development and agricultural economics and farm management were selected; COLANIM, department of animal breeding and genetics and animal nutrition were selected and COLPLANT, department of crop protection and plant physiology and crop production were selected. The third stage was proportionate random selection of $10 \%$ of the students in 100 level and 500 level of the selected departments to make up a sample size of 75 students for 100 level and 49 students for 500 level.

At the University of Ibadan, the first stage involved purposive selection of 100 level and 500 level students from the five departments under the Faculty of Agriculture i.e. agricultural extension and rural development, agricultural economics, agronomy, animal science and crop protection and environmental biology, for the same reason of being directly involved in agriculture. The second stage was proportionate random selection of $10 \%$ of students in 100 level and 500 level of the selected departments to make up a sample size of 45 students for 100 level and 72 students for 500 level. This gives a total sample size of 241 respondents.

Preferred course of study was operationalised on three-point rating scale of most preferred, preferred and not preferred with the scores of 2, 1 and 0 respectively. The most preferred course of the study is the course with the highest frequency. Perception of agriculture as a career choice was operationalised on five-point Likert type scale of strongly agreed (SA), agreed (A), undecided (U), disagreed (D) and strongly disagreed (SD) with scores of 5, 4, 3, 2 and 1 respectively. The reverse scores were applicable for negatively worded statements. The maximum obtainable score was 115 and minimum score was 45 . The mean score was computed and used to categorise as unfavourable for scores below the mean of 66 and favourable for scores from 66 and above. Self-esteem of the respondents was operationalised on 3 points rating scale of very correct (VC), partially correct (PC) and not correct (NC) with scores of 3,2 and 1 respectively. The scores obtain gives the level of 
Creative Commons User License: CC BY-NC-ND

Abstracted by: EBSCOhost, Electronic Journals Service (EJS),

Google Scholar, Journal Seek, Scientific Commons,

Food and Agricultural Organization (FAO), CABI and Scopus

http://eoi.citefactor.org/10.11226/v25i4
Journal of Agricultural Extension

Vol. 25 (4) October, 2021

ISSN(e): 24086851; ISSN(Print); 1119944X

http://journal.aesonnigeria.org

http://www.ajol.info/index.php/jae

Email: editorinchief@aesonnigeria.org

satisfaction with agriculture as a course of study (Self-esteem). The maximum obtainable score was 59 and minimum score was 18. The mean score was computed and used to categorise as low Self-esteem for scores below the mean of 35 and high Self-esteem for scores from 35 and above.

\section{Results and Discussion}

\section{Personal Characteristics of the Respondents}

Table 1 reveals that most of the students in UI were male $(65.0 \%)$, however, less than half of the students (46.8) were male in FUNAAB. The implication could be that more male students seek for admission in the conventional universities than in agriculture-based universities. With regards to family structure, the majority of the students in UI (82.1\%) and FUNAAB (74.2\%) hailed from monogamous homes. This could enhance the parental support received by the students, since such families are usually more compact and close-knit. Durisic and Bunijevac (2017) confirmed that parental support facilitates students' success in higher institutions. Table 1 also reveals that the mean number of persons per family for UI students was $5.8 \pm 1.5$ persons while the mean number of persons per family for FUNAAB students was 6.3 \pm 2.1 persons. This implies that students from FUNAAB come from a larger family size than their counterparts in U.I. The findings on parents' educational attainment indicated that $29.9 \%$ of students' parents in UI had HND/BSc certificates while in FUNAAB $31.5 \%$ of students' parents had NCE/ND certificates. This indicates that their parents were mostly literates and are likely to have some knowledge on career courses and can also influence the choice of their children's career. More of the students' parents were civil servants in UI (66.7\%) and FUNAAB (54.0\%). (Wangia, Waswa and Waudo, (2019) observed that parental occupational expectations can have a significant impact on the self-esteem and career decision making of university students. 
Creative Commons User License: CC BY-NC-ND

Abstracted by: EBSCOhost, Electronic Journals Service (EJS), Google Scholar, Journal Seek, Scientific Commons,

Food and Agricultural Organization (FAO), CABI and Scopus

http://eoi.citefactor.org/10.11226/v25i4
Journal of Agricultural Extension

Vol. 25 (4) October, 2021

ISSN(e): 24086851; ISSN(Print); 1119944X

http://journal.aesonnigeria.org

http://www.ajol.info/index.php/jae

Email: editorinchief@aesonnigeria.org

Table 1: Students' personal characteristics

\begin{tabular}{|c|c|c|c|c|}
\hline \multirow{2}{*}{$\begin{array}{l}\text { Variable } \\
\text { Sex }\end{array}$} & \multicolumn{2}{|l|}{ UI } & \multicolumn{2}{|c|}{ FUNAAB } \\
\hline & $\%$ & Mean & $\%$ & Mean \\
\hline & 65.0 & & 46.8 & \\
\hline Female & 35.0 & & 53.2 & \\
\hline \multicolumn{5}{|l|}{ Family structure } \\
\hline Monogamy & 82.1 & & 74.2 & \\
\hline Polygamy & 12.0 & & 20.2 & \\
\hline Single parent & 6.0 & & 5.6 & \\
\hline \multicolumn{5}{|l|}{ Number of members of family } \\
\hline $2-3$ & 3.4 & $5.8 \pm 1.5$ & 13.7 & $6.3 \pm 2.1$ \\
\hline $4-5$ & 44.4 & & 53.2 & \\
\hline $6-7$ & 41.0 & & 19.4 & \\
\hline $8-9$ & 8.5 & & 6.5 & \\
\hline $10-11$ & 2.6 & & 7.3 & \\
\hline \multicolumn{5}{|c|}{ Parents' educational attainment } \\
\hline No formal education & 0.9 & & 3.2 & \\
\hline Primary school certificate & 5.1 & & 6.5 & \\
\hline Secondary school certificate & 20.5 & & 27.4 & \\
\hline NCE/ND certificate & 19.7 & & 31.5 & \\
\hline HND/BSc. certificate & 29.9 & & 20.2 & \\
\hline Master degree & 13.7 & & 9.7 & \\
\hline PhD degree & 10.3 & & 1.6 & \\
\hline \multicolumn{5}{|l|}{ Parents' occupation } \\
\hline Artisan & 18.8 & & 25.0 & \\
\hline Civil servant & 66.7 & & 54.0 & \\
\hline Entrepreneur & 14.5 & & 21.0 & \\
\hline
\end{tabular}

\section{Students' Preferred Courses of Study}

Table 2 reveals that the most preferred course of study in the UI were medicine $(\bar{x}=1.14)$, followed by veterinary medicine $(\bar{x}=1.11)$ and engineering $(\bar{x}=1.08)$. Agriculture $(\bar{x}=0.88)$ was among the least sought-after course. On the contrary, agriculture $(\bar{x}=1.48)$ was the most preferred course of study in FUNAAB, followed by medicine $(\bar{x}=0.23)$, and veterinary medicine $(\bar{x}=0.21)$. This implies that students in agriculture-based university preferred agriculture to other courses. This could be because those who naturally have more interest in agriculture prefer studying the course in agriculture-based institution, whereas, most students in conventional university may be studying agriculture as a discipline against their initial intentions. According to Hellen and Kitainge (2016) students do not usually perform well in disciplines where they do not have interest. This poor performance could be an outcome of low self-esteem. 
Creative Commons User License: CC BY-NC-ND

Abstracted by: EBSCOhost, Electronic Journals Service (EJS),

Google Scholar, Journal Seek, Scientific Commons,

Food and Agricultural Organization (FAO), CABI and Scopus

http://eoi.citefactor.org/10.11226/v25i4
Journal of Agricultural Extension

Vol. 25 (4) October, 2021

ISSN(e): 24086851; ISSN(Print); 1119944X

http://journal.aesonnigeria.org

http://www.ajol.info/index.php/jae

Email: editorinchief@aesonnigeria.org

Table 2: Students' preferred course of study

\begin{tabular}{lllll}
\hline Course of study & Mean & Rank & Mean & Rank \\
\hline Agriculture & 0.88 & $7^{\text {th }}$ & 1.48 & $1^{\text {st }}$ \\
Veterinary & 1.11 & $2^{\text {nd }}$ & 0.21 & $3^{\text {rd }}$ \\
Medicine & & & & \\
Engineering & 1.08 & $3^{\text {rd }}$ & 0.15 & $6^{\text {th }}$ \\
Human Nutrition & 1.05 & $4^{\text {th }}$ & 0.20 & $4^{\text {th }}$ \\
Pharmacy & 0.76 & $8^{\text {th }}$ & 0.10 & $7^{\text {th }}$ \\
Medicine & 1.14 & $1^{\text {st }}$ & 0.23 & $2^{\text {nd }}$ \\
Pure Science & 0.89 & $6^{\text {th }}$ & 0.18 & $5^{\text {th }}$ \\
Others & 0.95 & $5^{\text {th }}$ & 0.15 & $6^{\text {th }}$ \\
\hline
\end{tabular}

\section{Students' Perception of Agriculture as a Career Choice}

Table 3 shows that the students indicated that agricultural science is an important field of study in UI $(\bar{x}=4.84)$ and FUNAAB $(\bar{x}=4.83)$. Meanwhile, FUNAAB students strongly agreed that agriculture should be made compulsory in secondary school $(\bar{x}=4.52)$.

This implies that the students in conventional and agriculture-based universities view agriculture as an important course. Agriculture is fast developing into a discipline with many career opportunities and someone with a career in agriculture is becoming more competitive in the job market. This implies that if government can intensify more support in the agriculture sector, more students will be willing to venture into agriculture as a career choice and the rate of unemployment, poverty and food insecurity will be reduced to a minimal level.

Data on Table 3 reveal that respondents in UI had unfavourable (87.2\%) perception towards agriculture compared to their counterparts in FUNAAB that had favourable $(82.7 \%)$ perception towards agriculture as a course of study. This means that students in agriculture-based universities feel worthy and creative about studying agriculture. It can therefore be inferred from the findings that students in agriculturebased university have a positive disposition towards agriculture which is expected to enhance their choice of agriculture as a course of study in the universities and as a professional career. 
Creative Commons User License: CC BY-NC-ND

Abstracted by: EBSCOhost, Electronic Journals Service (EJS), Google Scholar, Journal Seek, Scientific Commons,

Food and Agricultural Organization (FAO), CABI and Scopus

http://eoi.citefactor.org/10.11226/v25i4
Journal of Agricultural Extension

Vol. 25 (4) October, 2021

ISSN(e): 24086851; ISSN(Print); 1119944X

http://journal.aesonnigeria.org

http://www.ajol.info/index.php/jae

Email: editorinchief@aesonnigeria.org

Table 3: Students' perception of agriculture as a career in conventional and agriculture-based Universities

\begin{tabular}{|c|c|c|}
\hline Perception statements & $\begin{array}{l}\text { UI } \\
\text { Mean }\end{array}$ & $\begin{array}{l}\text { FUNAAB } \\
\text { Mean }\end{array}$ \\
\hline Agriculture is an important field of study. & 4.84 & 4.83 \\
\hline Agriculture should be compulsory at secondary level. & 4.43 & 4.53 \\
\hline Families and friends laugh, if one chooses Agriculture & 3.96 & 3.89 \\
\hline Agriculture is a "never do well course & 4.73 & 4.52 \\
\hline Agriculture is recognized as youth's last resort. & 3.05 & 2.84 \\
\hline Studying agriculture is encourage in my family & 3.89 & 4.15 \\
\hline Farmers live a reputable and decent life in society & 3.74 & 3.89 \\
\hline Agriculture is a lucrative vocation that sustain family & 4.50 & 4.46 \\
\hline Won't practice agriculture because it consumes time & 4.14 & 4.09 \\
\hline Agriculture allows one to practice other professions & 4.22 & 4.19 \\
\hline Farmers are not sociable and live-in dirty environment & 4.46 & 4.15 \\
\hline Agriculture is a poor man's job. & 4.62 & 4.34 \\
\hline It is not easy to access fund for Agriculture & 3.28 & 3.42 \\
\hline Diversification in agriculture creates more jobs & 4.39 & 4.11 \\
\hline It is difficult to get land to practice agriculture & 2.72 & 2.53 \\
\hline Agriculture cuts across many fields of specialisation & 4.39 & 4.15 \\
\hline $\begin{array}{l}\text { There is government support and subsidies to } \\
\text { enhance agriculture }\end{array}$ & 3.50 & 3.55 \\
\hline Some kinds of agriculture do not require much land & 4.10 & 4.13 \\
\hline \multirow[t]{3}{*}{ Perception level } & FUNAAB & \\
\hline & Percenta & \\
\hline & ge & \\
\hline Unfavourable (45-65) & 82.7 & \\
\hline
\end{tabular}

\section{Self-esteem of Agriculture Students}

Data on Table 4 show that $85.5 \%$ of the students in U.I had low self-esteem. This implies that agriculture students in U.I had low self-esteem. The reason could be that 
Creative Commons User License: CC BY-NC-ND

Abstracted by: EBSCOhost, Electronic Journals Service (EJS),

Google Scholar, Journal Seek, Scientific Commons,

Food and Agricultural Organization (FAO), CABI and Scopus

http://eoi.citefactor.org/10.11226/v25i4
Journal of Agricultural Extension

Vol. 25 (4) October, 2021

ISSN(e): 24086851; ISSN(Print); 1119944X

http://journal.aesonnigeria.org

http://www.ajol.info/index.php/jae

Email: editorinchief@aesonnigeria.org

they have doubt and feel inferior studying agriculture alongside students in other disciplines. Students with low esteem focused on trying to prove themselves to others because they lack self-confidence and often doubt their own worth and acceptability. On the contrary, agriculture students in FUNAAB had high self-esteem (89.5\%). Students in FUNAAB evaluated themselves more highly than those in U.I, which implies that they had better self-esteem that helps to lay a foundation for the development of right personality than students in UI. The high self-esteem among the students in FUNAAB could be attributed to their favourable perception about studying agriculture and feeling worthy and creative about studying agriculture. Negative feeling of one's self-worth, promoted by society (stereotype), perceived academic failure and an inadequate constructive environment, all serve to hinder students' self-esteem in studying agriculture.

Table 4: Agriculture students' self-esteem

\begin{tabular}{lll}
\hline Level of self-esteem & UI & FUNAAB \\
& Percentage & Percentage \\
\hline Low self-esteem (18-34) & 85.5 & 10.5 \\
High self-esteem (35-59) & 14.5 & 89.5 \\
Total & 100 & 100 \\
\hline \multicolumn{2}{l}{ Minimum=18, Maximum=59 and Mean=34.7 }
\end{tabular}

\section{Relationship between Personal Characteristics and Self-esteem of Students}

Data on Table 5 reveal that family structure $\left(X^{2}=8.04\right)$ was significantly related to selfesteem of students in UI, but was statistically insignificant for students in FUNAAB $\left(X^{2}=0.467\right)$. This implies that family structure was important in determining the selfesteem of students in UI than in FUNAAB. Wangia, Waswa and Waudo (2019) reported that the parents and teachers' negative pronouncements crush self-esteem. Therefore, agriculture students in $\mathrm{UI}$ could be battling with poor self-perception arising from family pressure over not being able to gain admission into their preferred courses compared to their counterparts from FUNAAB.

Similarly, sex $\left(x^{2}=9.412\right)$ was significantly related to self-esteem of students studying agriculture in FUNAAB and was insignificantly related for students in $U I\left(X^{2}=0.080\right)$. The reason could be due to the disparity in the proportion of male and female students in FUNAAB compared to UI. Moreover, sex as a factor could be 
Creative Commons User License: CC BY-NC-ND

Abstracted by: EBSCOhost, Electronic Journals Service (EJS),

Google Scholar, Journal Seek, Scientific Commons,

Food and Agricultural Organization (FAO), CABI and Scopus
Journal of Agricultural Extension

Vol. 25 (4) October, 2021

ISSN(e): 24086851; ISSN(Print); 1119944X

http://journal.aesonnigeria.org

http://www.ajol.info/index.php/jae

Email: editorinchief@aesonnigeria.org

suppressed in UI due to the influence of having students in other courses to worry about, whereas students tend to focus on gender for peer comparison on whether they are doing well or not in FUNAAB. Table 5 also reveals that family size $\left(X^{2}=0.183\right)$ was significantly related to self-esteem of students in UI, but was insignificantly related to self-esteem of students in FUNAAB $\left(X^{2}=0.017\right)$. The reason for the observation could be that in $\mathrm{UI}$ a lot of persuasions and energy are required to encourage agriculture students in UI who may not have chosen the course in the first instance, compared to students in FUNAAB who must had probably chosen agriculture related courses throughout in their entrance exam (first, second and third course).

Table 5: Relationship between personal characteristics and self-esteem of students

\begin{tabular}{llllll}
\hline $\begin{array}{l}\text { Personal } \\
\text { Characteristics }\end{array}$ & \multicolumn{6}{l}{ Conventional University (U.I) } & $\begin{array}{l}\text { Agriculture based University } \\
\text { (FUNAAB) }\end{array}$ \\
& DF & $x^{2}$ & $R$ & $X^{2}$ & $R$ \\
\hline Gender & 1 & 0.080 & & $9.412^{*}$ & \\
$\begin{array}{l}\text { Family structure } \\
\text { Family size }\end{array}$ & 2 & $8.039^{*}$ & & 0.467 & -0.082 \\
\hline
\end{tabular}

${ }^{*} p \leq 0.05$

\section{Relationship between Preferred Course of Study and Self-esteem}

Table 6 shows that preferred course of study $\left(x^{2}=0.306\right)$ was significantly related to self-esteem of students in UI but was insignificantly related to self-esteem of students in FUNAAB $\left(X^{2}=0.001\right)$. The reason for this disparity could be that in the conventional universities there are arrays of disciplines that the student could select but found themselves studying agriculture by coincidence. Meanwhile, students in agriculture-based university specifically selected agriculture as a course of study and the institution basically offer only agricultural related courses for study, hence their studying agriculture was based on choice.

\section{Relationship between Perception about Studying Agriculture as a Course and Self-esteem}

Table 6 reveals that there was no significant relationship between students' perception about studying agriculture as a course and self-esteem in U.I $(r=0.00)$. This means that their perception about agriculture as course of study did not influence their self-esteem. However, the perception of students about agriculture as a course of study was significantly related to self-esteem in FUNAAB $(r=0.400)$. Since students in FUNAAB had favourable disposition towards agriculture, this 
Creative Commons User License: CC BY-NC-ND

Abstracted by: EBSCOhost, Electronic Journals Service (EJS), Google Scholar, Journal Seek, Scientific Commons,

Food and Agricultural Organization (FAO), CABI and Scopus

http://eoi.citefactor.org/10.11226/v25i4
Journal of Agricultural Extension

Vol. 25 (4) October, 2021

ISSN(e): 24086851; ISSN(Print); 1119944X

http://journal.aesonnigeria.org

http://www.ajol.info/index.php/jae

Email: editorinchief@aesonnigeria.org

probably influenced their self-esteem positively. A favourable perception will result in higher self-esteem since negative comments about individuals and their activities adversely affect self-esteem (Wangia, Waswa and Waudo, 2019).

Table 6: Relationship between preferred course of study, perception about studying agriculture as a course and self-esteem

\begin{tabular}{lll}
\hline Variables & Ul & FUNAAB \\
& $\mathrm{R}$ & $\mathrm{R}$ \\
\hline Preferred course of study & $0.306^{*}$ & 0.076 \\
Perception to study & 0.003 & $0.400^{*}$ \\
agriculture & & \\
${ }^{*} \mathrm{p} \leq 0.05$ & &
\end{tabular}

\section{Difference between Self-esteem of Students in Agriculture based and Conventional Universities}

Table 7 shows that there was significant difference $(p \leq 0.05)$ in the self-esteem of students in FUNAAB and UI. The students in FUNAAB $(\bar{x}=39.48)$ had higher selfesteem than students in U.I ( $\bar{x}=29.68)$. This is because the students in FUNAAB believed that they can make things happen in their chosen career (agriculture) earlier than their counterparts in UI who would later on pick up interest in agriculture and make the best of it.

Table 7: Difference between self-esteem of students in FUNAAB and UI.

\begin{tabular}{lllll}
\hline Self-esteem & t-value & Mean & DF & $P$ \\
\hline U.I & 0.101 & 29.684 & 0.239 & $0.000^{*}$ \\
FUNAAB & & 39.484 & & \\
\hline
\end{tabular}

${ }^{*} \mathrm{p} \leq 0.05$

\section{Difference between Self-esteem of Students in $\mathbf{1 0 0}$ level and $\mathbf{5 0 0}$ level}

Table 8 shows that there was a significant difference $(p \leq 0.05)$ between the selfesteem of students in 100 level and 500 level in U.I, with 500 level students having higher self-esteem $(\bar{x}=29.78)$ than 100 level students $(\bar{x}=29.53)$. This is expected because as they progressed in the course of studying agriculture over the years, students might have found the course interesting and developed interest in it which will result in higher self-esteem on the long run. Contrary to the observed result for $\mathrm{UI}$, there was no significant ( $\mathrm{p}=0.122)$ difference between the self-esteem of students in 100 level and 500 level in FUNAAB. This means that the self-esteem of students in 100 level and 500 level in FUNAAB did not differ from each other. The plausible 
Creative Commons User License: CC BY-NC-ND

Abstracted by: EBSCOhost, Electronic Journals Service (EJS),

Google Scholar, Journal Seek, Scientific Commons,

Food and Agricultural Organization (FAO), CABI and Scopus

http://eoi.citefactor.org/10.11226/v25i4
Journal of Agricultural Extension

Vol. 25 (4) October, 2021

ISSN(e): 24086851; ISSN(Print); 1119944X

http://journal.aesonnigeria.org

http://www.ajol.info/index.php/jae

Email: editorinchief@aesonnigeria.org

reason for this could be that the students in FUNAAB had passion for agriculture as a course of study from the onset till the end.

Table 8: Difference between 100 level and 500 level Students in UI and FUNAAB

\begin{tabular}{lcll}
\hline Self-esteem & t-value & Mean & DF \\
\hline Ul & & & \\
100 level & $5.225^{\star}$ & 29.533 & 0115 \\
500 level & & 29.778 & \\
FUNAAB & & & \\
100 level & 0.452 & 39.333 & 0.122 \\
500 level & & 39.714 & \\
\hline
\end{tabular}

${ }^{*} \mathrm{p} \leq 0.05$

\section{Conclusion and Recommendations}

Students from UI preferred medicine and veterinary medicine when seeking admission into the university and had unfavourable perception about agriculture as a course of study, compared to their counterparts from FUNAAB, who preferred agriculture and medicine and had favourable perception about agriculture as a course of study. Agriculture students in U.I also had lower self-esteem compared to their counterparts in FUNAAB. Self-esteem of agriculture students in UI was influenced by family structure and preferred course of study, while sex and perception about agriculture as a course of study influenced self-esteem of students in FUNAAB. However, self-esteem of agriculture students improved with time as they progress from 100 to 500 level in Ul.

Faculties of agriculture or whatever designation given, should organise more orientation campaigns to showcase the success stories of graduates of agriculture in order to help boost the morale and self-esteem of intending students that want to take agriculture as alternative course to their preferred course of study. Similarly, efforts should be made to publicise agriculture at career resources centers. Professional agricultural organisations should reach out to agricultural student bodies in order to boost the self-esteem of students studying agriculture. Lastly, career counsellors in secondary schools should promote careers and opportunities in agriculture to make it popular and attractive to students and parents as they jointly plan students' academic pursuit. 
Creative Commons User License: CC BY-NC-ND

Abstracted by: EBSCOhost, Electronic Journals Service (EJS),

Google Scholar, Journal Seek, Scientific Commons,

Food and Agricultural Organization (FAO), CABI and Scopus

http://eoi.citefactor.org/10.11226/v25i4
Journal of Agricultural Extension

Vol. 25 (4) October, 2021

ISSN(e): 24086851; ISSN(Print); 1119944X

http://journal.aesonnigeria.org

http://www.ajol.info/index.php/jae

Email: editorinchief@aesonnigeria.org

\section{References}

Ahmed M. A. (2016). Introduction to the psychology of Self-Esteem. Chapter 1. In SelfEsteem: Perspective, influences and improvement strategies. Franklin Hollaway (Ed.). Nova Publishers. New York. Pp.:2.

Basil, U. E and Omole, O. O. (2017). Evaluating the impacts of rural-urban migration on agricultural productivity in Akoko south west local government area of Ondo State, South western Nigeria International Journal of Social Science and Economic Research Volume:02, Issue:05, Pp.: 3354 - 3368

Delango, M. W. (2019). The causes and consequences of rural-urban migration: The case of Wolaita Sodo town, Merhal Sub-City. Budapest International Research and Critics Institute-Journal (BIRCl-Journal) Volume 2, No 4, Pp.: 99-114

Durisic, M. and Bunijevac, M. (2017). Parental Involvement as an Important Factor for Successful Education. C E P S Journal Volume 7, No 3 Pp.: 137 - 153

Environmental Science. (2021). Agriculture and forestry careers. Retrieved from Careers in Agriculture \& Forestry | EnvironmentalScience.org.

Feed the Future (2020). Engaging youth in agriculture through information and communication technologies. Retrieved from Feed-the-Future-CaseStudy-Youth- AgICT.pdf (usaid.gov).

Hellen, M. J. and Kitainge, K.M. (2016). Influence of career preference on academic performance and graduation of male students: a case study of a university in

Western region of Kenya. Journal of Research in Humanities and Social Science. Volume 4, Issue 8. Pp.: 09-20

Junyi, Y. (2018). Teachers' role in developing healthy Self-esteem in young learners. A study of English language teachersin Finland. University of Eastern Finland, Academic press. Pp.:152.

Ojimba, T. P, Nwafor, S. A, Chigekwu, N and Onyekwere, A. (2018). Roles of students in academic performance in agricultural science in secondary schools in Emohua Local Government Area of Rivers State, Nigeria. Direct research journal of social science and educational studies. Volume 5; No: 5. Pp.: 75.

Oyaniran, T. (2020). Current state of Nigeria agriculture and agribusiness sector. AfCTA Workshop presentation. Pp.: 2 - 4. Retrieved from afcfta-agribusiness-current-statenigeria-agriculture-sector.pdf (pwc.com)

Stair, K., Danjean, S., Blackburn, J. J. and Bunch, J. C. (2016). A Major Decision: Identifying factors that influence agriculture students' choice of academic major. Journal of Human Science and Extension Volume 4, No. 2, Pp.: $111-124$.

Wangia, J., Waswa, F. and Waudo, J. (2019). Determinants of self-esteem, educational performance and career prospects among secondary school students in Navakholo 
Creative Commons User License: CC BY-NC-ND

Abstracted by: EBSCOhost, Electronic Journals Service (EJS),

Google Scholar, Journal Seek, Scientific Commons,

Food and Agricultural Organization (FAO), CABI and Scopus

http://eoi.citefactor.org/10.11226/v25i4
Journal of Agricultural Extension

Vol. 25 (4) October, 2021

ISSN(e): 24086851; ISSN(Print); 1119944X

http://journal.aesonnigeria.org

http://www.ajol.info/index.php/jae

Email: editorinchief@aesonnigeria.org

Constituency, Kakamega, Kenya. Journal of Education and Practice Vol.10, No.14, Pp.: $41-49$.

World Bank (2020). Rural population as a percentage of total population. Retrieved from Rural population (\% of total population) | Data (worldbank.org). 